University of Nebraska - Lincoln

DigitalCommons@University of Nebraska - Lincoln

\title{
Choice of Summer Fallow Replacement Crops Impacts Subsequent Winter Wheat
}

Drew J. Lyon

University of Nebraska-Lincoln, drew.lyon@wsu.edu

David Nielsen

University of Nebraska-Lincoln

Douglas Felter

University of Nebraska-Lincoln

Paul Burgener

University of Nebraska-Lincoln, pburgener2@unl.edu

Follow this and additional works at: https://digitalcommons.unl.edu/panhandleresext

Part of the Agriculture Commons

Lyon, Drew J.; Nielsen, David; Felter, Douglas; and Burgener, Paul, "Choice of Summer Fallow Replacement Crops Impacts Subsequent Winter Wheat" (2007). Panhandle Research and Extension Center. 12.

https://digitalcommons.unl.edu/panhandleresext/12

This Article is brought to you for free and open access by the Agricultural Research Division of IANR at DigitalCommons@University of Nebraska - Lincoln. It has been accepted for inclusion in Panhandle Research and Extension Center by an authorized administrator of DigitalCommons@University of Nebraska - Lincoln. 


\title{
Choice of Summer Fallow Replacement Crops Impacts Subsequent Winter Wheat
}

\author{
Drew J. Lyon,* David C. Nielsen, Douglas G. Felter, and Paul A. Burgener
}

\begin{abstract}
Winter wheat (Triticum aestivum L.) is the foundation of dryland cropping systems in the Central Great Plains. The objective of this study was to quantify the effects of four short-season spring-planted crops used to replace summer fallow on the subsequent winter wheat crop. Wheat was seeded into four crop stubbles [spring triticale ( $\times$ Triticosecale Wittmack), dry pea (Pisum sativum L.), foxtail millet (Setaria italica L. Beauv.), and proso millet (Panicum miliaceum L.)] at sites near Akron, CO, and Sidney, NE, in the fall of 2004 and 2005. These summer fallow replacement crops were planted into silt loam soils at three different soil water levels at planting (low, medium, and high). Winter wheat water use was $3.6 \mathrm{~cm}$ greater, and grain yield was $662 \mathrm{~kg} \mathrm{ha}^{-1}$ greater in the high water treatment compared with the low water treatment averaged across all sites and years. Winter wheat used an average of $4.3 \mathrm{~cm}$ more water following early planted summer crops (triticale and dry pea) than after late planted summer crops (foxtail and proso millet), but this increased water use did not consistently translate into increased grain yield as a result of terminal drought at Sidney in 2006. The high water treatment always had a positive net return. The high cost of pea seed $\left(\$ 3.30 \mathrm{~kg}^{-1}\right.$, USD) strongly reduced profitability. The flexible summer fallow cropping system appears to be most applicable when using short-duration summer annual forage crops such as triticale and foxtail millet.
\end{abstract}

$\mathrm{I}_{\mathrm{v}}^{\mathrm{N}}$ Nhe Central Great Plains, dryland agriculture developed around winter wheat production. A variable climate with unpredictable precipitation and other weather conditions made, and continues to make, dryland farming in the region inherently risky (Dhuyvetter et al., 1996). Summer fallow, the practice of controlling all plant growth during the noncrop season, was quickly adopted in the region to increase the chances for successful establishment and development of winter wheat and to stabilize winter wheat yields (Lyon et al., 1995; Dhuyvetter et al., 1996; Peterson et al., 1996; Farahani et al., 1998). Winter wheat-fallow is the predominant crop rotation in the Central Great Plains.

When summer fallow began, fallow management often involved numerous tillage operations, including the use of inversion tillage, which buried most crop residues. Less than $20 \%$ of precipitation received during summer fallow was stored in the soil for the following winter wheat crop with these practices (Greb, 1979). As

D.J. Lyon and P.A. Burgener, Univ. of Nebraska Panhandle Research \& Extension Center, 4502 Ave. I, Scottsbluff, NE 69361; D.C. Nielsen, USDA-ARS Central Great Plains Research Station, 40335 County Road GG, Akron, CO 80720; and D.G. Felter, John Deere, 8000 Jersey Ridge Road, Davenport, IA 52807. A contribution of the Univ. of Nebraska Agric. Res. Div., supported in part by funds provided through the Hatch Act. Additional support was provided by the Nebraska Wheat Board. Received 19 Oct. 2006. *Corresponding author (dlyon1@unl.edu).

Published in Agron. J. 99:578-584 (2007).

Dryland Cropping Systems

doi:10.2134/agronj2006.0287

(C) American Society of Agronomy

677 S. Segoe Rd., Madison, WI 53711 USA

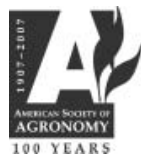

noninversion tillage and herbicides replaced inversion tillage, more crop residue was left on the soil surface. Precipitation storage efficiency increased during this period of time, but the efficiency of soil water storage during the fallow period has been stagnant at about $40 \%$ since the 1970s (Greb, 1983; Unger, 1984; Tanaka and Aase, 1987; Dao, 1993; Peterson et al., 1996; Nielsen et al., 2005).

McGee et al. (1997) suggested that greater water storage efficiency could be achieved by terminating fallow in the spring and planting a summer crop. The principle behind cropping intensification is replacement of soil evaporation with crop transpiration (Farahani et al., 1998). Intensified systems in the region generally produce two crops in $3 \mathrm{yr}$ or three crops in $4 \mathrm{yr}$ through the addition of summer crops such as corn (Zea mays L.), sunflower (Helianthus annuus L.), sorghum [Sorghum bicolor (L.) Moench], or proso millet.

Intensification of dryland cropping systems has resulted in pronounced increases in biomass and grain production on an annual basis across much of the Central and Southern Great Plains (Peterson et al., 1993, 1996; Norwood, 1994; Jones and Popham, 1997). Peterson and Westfall (2004) found that intensification of cropping systems increased net return to producers in eastern Colorado by 25 to $45 \%$ compared with wheatfallow. Intensified dryland cropping systems have also increased potentially active surface soil organic $\mathrm{C}$ and $\mathrm{N}$ (Peterson et al., 1998), effectively controlled winter annual grass weeds in winter wheat (Daugovish et al., 1999), and reduced yield loss in wheat resulting from soilborne disease (Krupinsky et al., 2002).

However, cropping intensification that eliminates summer fallow can have negative consequences. Elimination of the summer fallow period in eastern Colorado resulted in a significant reduction of available soil water at wheat planting and subsequent wheat yield (Nielsen et al., 2002). When fallow was replaced with proso millet in a wheat-corn-fallow rotation, available soil water content at wheat planting was decreased by $48 \%$ $(9.8 \mathrm{~cm})$. Wheat yield in the wheat-corn-millet system averaged $52 \%\left(1530 \mathrm{~kg} \mathrm{ha}^{-1}\right)$ less than in the wheatcorn-fallow system. Wheat yield has been reported to be strongly correlated with available soil water at wheat planting (Nielsen et al., 1999; Nielsen et al., 2002; Nielsen and Vigil, 2005), with the response ranging from 39.7 to $282.9 \mathrm{~kg} \mathrm{ha}^{-1} \mathrm{~cm}^{-1}$. The yield response to available soil water increased with increasing precipitation during May and June.

Lyon et al. (2004) studied the impact of replacing summer fallow with various spring-planted crops prior to winter wheat seeding. Oat (Avena sativa L.) and pea for forage or proso millet for grain were economically competitive with systems that included summer fallow, despite reducing winter wheat yields by $23 \%\left(450 \mathrm{~kg} \mathrm{ha}^{-1}\right)$ 
Table 1. Plant available soil water in the 0 - to $120-\mathrm{cm}$ soil profile at planting time for the summer fallow replacement crops at Akron, CO, and Sidney, NE (amended from Felter et al., 2006).

\begin{tabular}{lcrcc}
\hline & & \multicolumn{3}{c}{ Water treatment } \\
\cline { 3 - 5 } Site & Year & Low & Medium & High \\
\cline { 3 - 5 } Akron & & & cm & \\
& 2004 & 8.5 & 13.1 & 17.1 \\
Sidney & 2005 & 11.0 & 15.1 & 20.2 \\
& 2004 & 3.5 & 6.6 & 13.4 \\
& 2005 & 17.4 & 19.1 & 21.0 \\
\hline
\end{tabular}

and $34 \%\left(690 \mathrm{~kg} \mathrm{ha}^{-1}\right)$ compared with wheat after fallow. Soil water content at wheat planting was reduced by $27 \%$ following oat + pea, and $34 \%$ following proso millet, when compared with fallow. Net returns of systems including oat + pea for forage or proso millet were similar to returns of wheat-fallow, with the additional benefit of minimizing the negative effects of fallow and spreading marketing risk over two crops.

Felter et al. (2006) investigated the potential for using short-season spring-planted crops as a summer fallow replacement in a dynamic cropping system based on soil water availability at planting. They found that soil water at planting could be a useful indicator of potential yield for crops such as triticale or foxtail millet for forage, particularly when crop growth was limited by growing season precipitation, but soil water at planting was not a useful indicator of yield for dry pea grown for grain.

The objective of this study was to quantify the effects of the four short-season spring-planted crops used to replace summer fallow in the study reported by Felter et al. (2006) on the subsequent winter wheat crop. We also quantified the 2-yr economic returns of the various summer fallow replacement crops followed by winter wheat.

\section{MATERIALS AND METHODS}

Research was conducted from 2004 through 2006 at the High Plains Agricultural Laboratory $\left(41^{\circ} 12^{\prime} \mathrm{N}, 103^{\circ} 0^{\prime} \mathrm{W}, 1315\right.$ $m$ elevation) located near Sidney, NE; and the USDA-ARS Central Great Plains Research Station $\left(40^{\circ} 09^{\prime} \mathrm{N}, 103^{\circ} 09^{\prime} \mathrm{W}\right.$, $1383 \mathrm{~m}$ elevation) located near Akron, CO. The soil type at Sidney was a Keith silt loam (fine-silty, mixed, superactive, mesic Aridic Argiustolls) with a $\mathrm{pH}$ of 7.0 and an organic matter content of $\approx 20 \mathrm{~g} \mathrm{~kg}^{-1}$ in the surface $15 \mathrm{~cm}$. At Akron, the soil type was a Weld silt loam (fine, smectitic, mesic Aridic Argiustolls) with a $\mathrm{pH}$ of 7.0 and organic matter content of about $15 \mathrm{~g} \mathrm{~kg}^{-1}$ in the surface $15 \mathrm{~cm}$.
Winter wheat 'Alliance' was seeded at Sidney at a rate of $67 \mathrm{~kg} \mathrm{ha}^{-1}$ on 14 Sept. 2004 and 2005. Wheat was reseeded on 20 Sept. 2004 at a rate of $56 \mathrm{~kg} \mathrm{ha}^{-1}$ because of poor wheat stands resulting from soil crusting. At Akron, Alliance was seeded at a rate of $67 \mathrm{~kg} \mathrm{ha}^{-1}$ on 27 Sept. 2004 and 21 Sept. 2005. Row spacings were $25 \mathrm{~cm}$ at Sidney and $19 \mathrm{~cm}$ at Akron. Wheat was seeded across previous field studies described by Felter et al. (2006). Previous studies were conducted as factorial experiments with a split-plot design and four replications per field site. Three differential soil water levels were created prior to planting the short-season summer crops, and these water treatments served as the whole plot treatments. One of the three water treatments received no supplemental water (low treatment). Supplemental water was applied to attain the medium and high water treatments. The amount for each of these treatments varied by year and location, and was applied to achieve a range of soil water levels at planting (Table 1). The values for the high starting soil water treatment are at approximately field capacity for a silt loam soil, that is, 20 to $25 \mathrm{~cm}$ in the surface $120 \mathrm{~cm}$ of soil (Klocke and Hergert, 1990). Four summer annual crops (spring triticale, dry pea, foxtail millet, and proso millet) were the subplot treatments. Triticale and dry pea were planted in early April, while foxtail and proso millets were planted in early June. Whole plot treatment size was 18.3 by $9.1 \mathrm{~m}$ at Sidney and 24.4 by $12.2 \mathrm{~m}$ at Akron. Subplot size was 4.6 by $9.1 \mathrm{~m}$ at Sidney and 6.1 by $12.2 \mathrm{~m}$ at Akron.

Supplemental water was applied at Sidney during the 2005 2006 wheat growing season. Dry surface soil conditions in the fall of 2005 resulted in no wheat seedling emergence in plots that had previously been seeded to proso or foxtail millet. Approximately $13 \mathrm{~mm}$ of water was applied to the entire plot area on 28 Sept. 2005 to initiate germination and seedling emergence. Supplemental water was again applied on 1 and 8 June 2006 at a rate of $\approx 25 \mathrm{~mm}$ each time to partially compensate for spring precipitation that was well below average (Table 2).

At Sidney, granular urea fertilizer was applied at a rate of $45 \mathrm{~kg} \mathrm{~N}^{-1}$ on 7 Oct. 2004 and at $34 \mathrm{~kg} \mathrm{~N}$ ha $^{-1}$ on 4 Oct. 2005. At Akron, $67 \mathrm{~kg} \mathrm{~N} \mathrm{ha}^{-1}$ was applied as a liquid on the surface beside each row and $9.6 \mathrm{~kg} \mathrm{P}^{-1}$ was applied as a granule in the row at seeding in both years.

Glyphosate [ $N$-(phosphonomethyl)glycine] was used to control weeds prior to seeding winter wheat. Herbicides were not used for weed control in the growing wheat with the exception of Akron in 2006, when fluroxypyr $\{[$ (4-amino-3,5-dichloro-6fluoro-pyridyl)oxy]acetic acid $+2,4-\mathrm{D}$ [(2,4-dichlorophenoxy)acetic acid] ester were applied at $144+578 \mathrm{~g}$ a.e. ha $^{-1}$ on 14 April.

Crop water use was calculated by the water balance method using soil water measurements. Runoff and deep percolation were assumed to be negligible. At Sidney, gravimetric soil water content was multiplied by soil bulk density to determine volumetric water content for the surface $120 \mathrm{~cm}$ during the

Table 2. Precipitation and supplemental irrigation (in parenthesis) by month during the 2004-2005 and 2005-2006 winter wheat growing seasons at Akron, CO, and Sidney, NE.

\begin{tabular}{|c|c|c|c|c|c|c|c|c|}
\hline Site & Year & September & October & November-March & April & May & June & September-Jun \\
\hline \multirow[t]{3}{*}{ Akron } & 2004-2005 & 43 & 19 & 45 & 42 & 62 & 86 & 297 \\
\hline & $2005-2006$ & 10 & 75 & 43 & 23 & 37 & 18 & 206 \\
\hline & 30-yr normal $\dagger$ & 25 & 22 & 72 & 36 & 76 & 58 & 289 \\
\hline \multirow[t]{3}{*}{ Sidney } & 2004-2005 & 61 & 18 & 24 & 54 & 50 & 154 & 361 \\
\hline & $2005-2006$ & $8(+13)$ & 66 & 25 & 19 & 12 & $82(+51)$ & $212(+64)$ \\
\hline & 30-yr normal & 33 & 21 & 62 & 38 & 73 & 70 & 297 \\
\hline
\end{tabular}

$\dagger$ Thirty-year normals for each site were obtained from the High Plains Regional Climate Center located at the University of Nebraska-Lincoln and at www.hprcc.unl.edu (verified 10 Jan. 2007). 
2004-2005 wheat season and for the surface $30 \mathrm{~cm}$ during the 2005-2006 season. During both seasons at Akron, and during the 2005-2006 season at Sidney, soil water measurements at 45,75 , and $105 \mathrm{~cm}$ were made using a neutron probe (Campbell Pacific 503 DR, Campbell Pacific, Pacheco, CA). Gravimetric soil water samples from the plot area were used to calibrate the neutron probe. Time-domain reflectometry was used at Akron to determine soil water content in the surface $30 \mathrm{~cm}$ of soil. Measurement sites were located near the center of each subplot. Amount of plant available water was determined by subtracting field-observed lower limits of plant water extraction at each site from the total water content at each sampling interval. Lower limits for water extraction at Sidney were $0.09,0.11,0.08$, and $0.06 \mathrm{~cm}^{3} \mathrm{~cm}^{-3}$ for the 0 - to $30-, 30$ - to 60-, 60- to 90-, and 90- to $120-\mathrm{cm}$ intervals, respectively. These values represent the lowest observed volumetric water contents in winter wheat at Sidney. At Akron, the values were $0.09,0.12,0.07$, and $0.06 \mathrm{~cm}^{3} \mathrm{~cm}^{-3}$, respectively, for the same soil depth intervals.

Immediately prior to harvest, the number of reproductive tillers in a meter of row was determined in each plot. Plants from this meter of row were clipped at the soil surface, dried for $3 \mathrm{wk}$, and weighed. Grain was threshed and weighed. Harvest index was calculated by dividing the grain weight by the total weight of the nonthreshed sample.

Plots were machine harvested for grain yield. The harvested areas at Sidney were $12.1 \mathrm{~m}^{2}$ in 2005 and $13.3 \mathrm{~m}^{2}$ in 2006 . At Akron, the harvested areas were $17.8 \mathrm{~m}^{2}$ in 2005 and $15.4 \mathrm{~m}^{2}$ in 2006. Moisture and test weight of grain crops were determined using a grain analyzer (GAC-2000, Dickey-John, Auburn, IL). Grain yield was adjusted to $125 \mathrm{~g} \mathrm{~kg}^{-1}$ water content.

Gross returns for each crop were calculated using 5-yr average prices. Winter wheat and proso millet prices were from local markets. Triticale and foxtail millet hay prices were based on local alfalfa hay prices adjusted to $80 \%$ of the alfalfa (Medicago sativa L.) price. This adjustment reflects the lack of market reporting in summer annual forages and a perceived lower value for these forages. The nearest market for dry pea is located in eastern North Dakota, so the 5-yr average price for North Dakota was used. Cost of production budgets were developed for each summer annual crop and the winter wheat using the University of Nebraska Budget Generator. Net return, as defined for this project, is a residual return to land and management, without any USDA farm program payments or crop insurance cost or indemnities. Annualized net return is determined by summing the return from the summer annual crop and winter wheat in the following year. This total value is halved to determine the annualized net return.

Data were analyzed with PROC MIXED (SAS Inst., 2001). There were significant site-year $\times$ crop and site-year $\times$ water treatment interactions for many of the parameters measured, which prevented pooling of data across sites and years. There were no significant crop $\times$ water treatment interactions for any of the parameters measured, and therefore, crop treatment means are averaged across all water treatments and water treatment means are averaged across all crop treatments. Treatment means, with the exception of economic net returns, were separated by a priori single degree of freedom orthogonal contrasts. Net return means were separated using Fishers' protected LSD at the 0.05 probability level.

\section{RESULTS AND DISCUSSION}

In 2004 at Sidney and 2005 at Akron, foxtail and proso millet were not successfully grown. Hail destroyed the crop in 2004 and soil crusting prevented successful es- tablishment in 2005. As a result, there are two site-years of data for wheat after proso and foxtail millet and four site-years of data for wheat following triticale and dry pea.

Precipitation during the two winter wheat seasons varied from slightly above normal in 2004-2005 to well below average in 2005-2006 (Table 2). At Sidney, dry soil conditions at planting in 2005, combined with little precipitation after planting, resulted in the need to apply $13 \mathrm{~mm}$ of supplemental irrigation on 28 September in order to germinate wheat seed planted into foxtail or proso millet stubble. Supplemental irrigation was again applied at Sidney in early June of 2006 to partially compensate for a very hot and dry period in May and early June.

\section{Soil Water and Water Use by Wheat}

The differences in water content among the three water treatments at the time of summer fallow replacement crop planting (Table 1) were still apparent at the subsequent wheat seeding (Table 3), and also varied by previous crop treatment. Soil water at wheat seeding was always greater in the high water treatment than in the low water treatment. Apparently, the short-season summer crops used in this study did not need, or were unable to use, all the available soil water in the high water treatments. Consequently, this unused soil water was available for use by the subsequent winter wheat crop.

Plant available soil water at wheat seeding was not affected by previous crop in three of four site-years. However, at Sidney in 2005, plant available water in the surface $120 \mathrm{~cm}$ of soil at wheat seeding averaged $17.0 \mathrm{~cm}$ following early planted summer crops (triticale and dry pea) and $11.0 \mathrm{~cm}$ following late planted crops (foxtail and proso millets). Triticale was harvested 24 June and dry pea 20 July 2005, while foxtail was harvested 16 Aug. and proso millet $30 \mathrm{Aug}$. 2005. The earlier harvest dates of triticale and dry pea allowed greater opportunity to capture and store precipitation in the soil prior to winter

Table 3. Influence of previous summer crop and starting soil water level on plant available water in the surface $120 \mathrm{~cm}$ of soil at the time of seeding winter wheat at Akron, CO, and Sidney, NE, in 2004 and 2005.

\begin{tabular}{|c|c|c|c|c|}
\hline \multirow[b]{2}{*}{ Treatment } & \multicolumn{2}{|c|}{ Akron, CO } & \multicolumn{2}{|c|}{ Sidney, NE } \\
\hline & 2004 & 2005 & 2004 & 2005 \\
\hline & & . & & 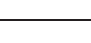 \\
\hline \multicolumn{5}{|l|}{ Crop } \\
\hline Triticale & 9.4 & 13.9 & 5.7 & 18.1 \\
\hline Dry pea & 9.6 & 14.6 & 6.8 & 15.8 \\
\hline Foxtail millet & 8.5 & - & - & 12.3 \\
\hline Proso millet & 9.1 & - & - & 9.7 \\
\hline \multicolumn{5}{|l|}{ Soil water level } \\
\hline Low & 7.8 & 11.5 & 5.3 & 12.8 \\
\hline Medium & 10.1 & 14.4 & 5.4 & 13.6 \\
\hline High & 9.5 & 16.9 & 8.2 & 15.5 \\
\hline \multicolumn{5}{|l|}{ Contrasts } \\
\hline Early vs. late $\dagger$ & 0.242 & - & - & $<0.001$ \\
\hline Triticale vs. dry pea & 0.805 & 0.381 & 0.227 & 0.002 \\
\hline Foxtail vs. proso & 0.508 & - & - & $<0.001$ \\
\hline Low vs. high & 0.133 & 0.042 & 0.014 & $<0.001$ \\
\hline
\end{tabular}

† Triticale and dry pea were planted in early April while foxtail and proso millets were planted in early June. 
wheat seeding. Within each planting date grouping at Sidney in 2005, available soil water at wheat seeding was greater following the forage crop than the grain crop. Triticale and foxtail millet were harvested for forage earlier than their paired grain crops. This not only allowed for more time to capture and store precipitation in the soil after harvest, but it also reduced the amount of soil water extracted by the forage crop compared with the grain crop. Precipitation at Sidney during the 2005 summer crop season (April-August) was $9.5 \mathrm{~cm}$ greater than the $30-y r$ average of $28.6 \mathrm{~cm}$. This was the only siteyear where precipitation during the summer crop season was above the 30-yr average. This may partially explain why differences in plant available soil water at winter wheat seeding were only observed at Sidney in 2005.

Water use by winter wheat varied as a result of the previous crop and water treatments (Table 4) and in a manner that was similar to the differences observed for plant available soil water at winter wheat seeding (Table 3). This would be expected as the amount of soil water at wheat seeding has a strong influence on winter wheat water use (Musick et al., 1994; Nielsen et al., 2002; Stone and Schlegel, 2006). However, despite similar initial starting soil water amounts, wheat grown after triticale and dry pea at Akron in 2004-2005 used an average of $27.9 \mathrm{~cm}$ of water compared with $25.5 \mathrm{~cm}$ after foxtail and proso millet. This difference of $2.4 \mathrm{~cm} \mathrm{oc}-$ curred despite just a $0.7 \mathrm{~cm}$ average difference in starting soil water. This appears to be primarily driven by the increased water use of wheat after dry pea. In a summary of published results, Angus and van Herwaarden (2001) noted that break crops, or crops inserted into a rotation to break the life cycle of cereal root diseases, and $\mathrm{N}$ fertilizer have affected water use and yield. Increased water use following break crops was attributed to a healthier root system.

\section{Grain Yield}

Winter wheat grain yield was greater in the high water treatment than in the low water treatment at three of the
Table 5. Influence of previous summer crop and starting soil water level on the grain yield of the subsequent winter wheat crop at Akron, CO, and Sidney, NE, in 2004-2005 and 2005-2006.

\begin{tabular}{|c|c|c|c|c|}
\hline \multirow[b]{2}{*}{ Treatment } & \multicolumn{2}{|c|}{ Akron, CO } & \multicolumn{2}{|c|}{ Sidney, NE } \\
\hline & 2004 & 2005 & 2004 & 2005 \\
\hline & & - & -1 & \\
\hline \multicolumn{5}{|l|}{ Crop } \\
\hline Triticale & 685 & 1720 & 1530 & 1920 \\
\hline Dry pea & 742 & 1700 & 1900 & 1660 \\
\hline Foxtail millet & 373 & - & - & 2250 \\
\hline Proso millet & 598 & - & - & 2230 \\
\hline \multicolumn{5}{|l|}{ Soil water level } \\
\hline Low & 318 & 1370 & 1240 & 1870 \\
\hline Medium & 687 & 1590 & 1550 & 2060 \\
\hline High & 794 & 2170 & 2360 & 2120 \\
\hline \multicolumn{5}{|l|}{ Contrasts } \\
\hline Early vs. late $\dagger$ & 0.059 & - & - & 0.001 \\
\hline Triticale vs. dry pea & 0.733 & 0.895 & 0.104 & 0.168 \\
\hline Foxtail vs. proso & $\mathbf{0 . 1 8 1}$ & - & - & 0.927 \\
\hline Low vs. high & 0.002 & 0.002 & $<0.001$ & 0.134 \\
\hline
\end{tabular}

$\dagger$ Triticale and dry pea were planted in early April while foxtail and proso millets were planted in early June.

four site-years (Table 5). Only at Sidney in 2005-2006 was there no significant difference in wheat yield between these two water treatments.

The effect of preceding crop on winter wheat grain yield varied between site-years. There were no differences in yield for wheat following crops planted at the same time, for example, between triticale or dry pea, at any site or year. At site-years where all four crops were successfully grown (Akron 2004 and Sidney 2005), there was a difference in yield between wheat grown after early planted summer crops and wheat grown after late planted summer crops. At Akron in 2004-2005, wheat yield averaged $714 \mathrm{~kg} \mathrm{ha}^{-1}$ following early planted summer crops and $486 \mathrm{~kg} \mathrm{ha}^{-1}$ following late planted crops. Although not a significant difference at the $5 \%$ probability level, this yield increase coincided with a $2.4 \mathrm{~cm}$ average increase in water use by winter wheat following triticale or dry pea compared with winter wheat following foxtail or proso millet (Table 4). However, at Sidney

Table 4. Influence of previous summer crop and starting soil water level on water use in the subsequent winter wheat crop at Akron, CO, and Sidney, NE, in 2004-2005 and 2005-2006.

\begin{tabular}{|c|c|c|c|c|}
\hline \multirow[b]{2}{*}{ Treatment } & \multicolumn{2}{|c|}{ Akron, CO } & \multicolumn{2}{|c|}{ Sidney, NE } \\
\hline & 6 Oct. 2004-12 July 2005 & 29 Sept. 2005-26 June 2006 & 14 Sept. 2004-11 July 2005 & 14 Sept. 2005-28 June 2006 \\
\hline \multicolumn{5}{|l|}{ Crop } \\
\hline Triticale & 27.0 & 32.6 & 31.2 & 35.0 \\
\hline Dry pea & 28.8 & 33.6 & 32.3 & 32.1 \\
\hline Foxtail millet & 25.8 & - & - & 29.3 \\
\hline Proso millet & 25.1 & - & - & 25.6 \\
\hline \multicolumn{5}{|l|}{ Soil water level } \\
\hline Low & 25.6 & 29.7 & 30.5 & 29.7 \\
\hline Medium & 27.1 & 33.0 & 30.4 & 30.2 \\
\hline High & 27.3 & 36.6 & 34.3 & 31.7 \\
\hline \multicolumn{5}{|l|}{ Contrasts } \\
\hline Early vs. late $\dagger$ & 0.002 & - & - & $<\mathbf{0 . 0 0 1}$ \\
\hline Triticale vs. dry pea & 0.093 & 0.466 & 0.436 & $<\mathbf{0 . 0 0 1}$ \\
\hline Foxtail vs. proso & 0.546 & - & - & $<0.001$ \\
\hline Low vs. high & 0.071 & $<\mathbf{0 . 0 0 1}$ & 0.043 & $<\mathbf{0 . 0 0 1}$ \\
\hline
\end{tabular}

$\dagger$ Triticale and dry pea were planted in early April while foxtail and proso millets were planted in early June. 
in 2005-2006, wheat yield was $1790 \mathrm{~kg} \mathrm{ha}^{-1}$ following early planted summer crops and $2240 \mathrm{~kg} \mathrm{ha}^{-1}$ following late planted crops. This difference in yield occurred despite wheat using $6.1 \mathrm{~cm}$ more water when it followed early planted summer crops (Table 4).

Plant available soil water at wheat seeding at Akron in 2004 averaged $9.5 \mathrm{~cm}$ following early planted crops and $8.8 \mathrm{~cm}$ following late planted crops (Table 3). At Sidney in 2005, available soil water at wheat seeding averaged $17.0 \mathrm{~cm}$ following early planted crops and $11.0 \mathrm{~cm}$ following late planted crops. The greater difference in starting soil water between early and late planted summer crops at Sidney compared with Akron may partially explain the difference in winter wheat response to the crop treatments between these two sites. At Sidney, winter wheat following the early planted summer crops germinated and began rapid growth about 2 wk earlier than winter wheat following the late planted summer crops. Supplemental irrigation was required to germinate wheat seed planted into foxtail and proso millet stubble. The earlier start of wheat growth following the early planted summer crops, combined with greater soil water availability and above normal autumn (September and October) precipitation at Sidney (Table 2), resulted in a visible growth advantage to wheat plants following triticale and pea that persisted throughout most of the season. However, hot and dry conditions in May and June resulted in greater terminal drought stress in wheat following triticale and dry pea than in wheat following foxtail or proso millet.

The effect of terminal drought can be seen by looking at the number of reproductive tillers (Table 6) and harvest index data (Table 7). Wheat following early planted summer crops at Sidney averaged 200 reproductive tillers $\mathrm{m}^{-1}$ of row compared with 163 tillers $\mathrm{m}^{-1}$ after late planted summer crops. However, an increased number of reproductive tillers did not translate into increased yield because of terminal drought stress. The

Table 6. Influence of previous summer crop and starting soil water level on the number of reproductive tillers in the subsequent winter wheat crop at Akron, CO, and Sidney, NE, in 2004-2005 and 2005-2006.

\begin{tabular}{|c|c|c|c|c|}
\hline \multirow[b]{2}{*}{ Treatment } & \multicolumn{2}{|c|}{ Akron, CO } & \multicolumn{2}{|c|}{ Sidney, NE } \\
\hline & 2004-2005 & 2005-2006 & 2004-2005 & 2005-2006 \\
\hline & & no. $\mathrm{m}^{-}$ & of row & \\
\hline \multicolumn{5}{|l|}{ Crop } \\
\hline Triticale & 201 & 187 & 247 & 214 \\
\hline Dry pea & 172 & 179 & 255 & 186 \\
\hline Foxtail millet & 154 & - & - & 164 \\
\hline Proso millet & 183 & - & - & 161 \\
\hline \multicolumn{5}{|l|}{ Soil water level } \\
\hline Low & 155 & 201 & 241 & 165 \\
\hline Medium & 181 & 172 & 246 & 184 \\
\hline High & 196 & 177 & 266 & 194 \\
\hline \multicolumn{5}{|l|}{ Contrasts } \\
\hline Early vs. late $\dagger$ & 0.111 & - & - & $<0.001$ \\
\hline Triticale vs. dry pea & 0.061 & 0.612 & 0.638 & 0.014 \\
\hline Foxtail vs. proso & 0.064 & - & - & 0.753 \\
\hline Low vs. high & 0.004 & 0.231 & 0.207 & 0.004 \\
\hline
\end{tabular}

$\dagger$ Triticale and dry pea were planted in early April while foxtail and proso millets were planted in early June.
Table 7. Influence of previous summer crop and starting soil water level on the harvest index of the subsequent winter wheat crop at Akron, CO, and Sidney, NE, in 2004-2005 and 2005-2006.

\begin{tabular}{|c|c|c|c|c|}
\hline \multirow[b]{2}{*}{ Treatment } & \multicolumn{2}{|c|}{ Akron, CO } & \multicolumn{2}{|c|}{ Sidney, NE } \\
\hline & 2004-2005 & 2005-2006 & 2004-2005 & 2005-200 \\
\hline & & $-\mathrm{g}$ & 1 & \\
\hline \multicolumn{5}{|l|}{ Crop } \\
\hline Triticale & 0.102 & 0.294 & 0.205 & 0.150 \\
\hline Dry pea & 0.149 & 0.317 & $\mathbf{0 . 2 3 3}$ & 0.174 \\
\hline Foxtail millet & 0.074 & - & - & 0.227 \\
\hline Proso millet & 0.110 & - & - & 0.258 \\
\hline \multicolumn{5}{|l|}{ Soil water level } \\
\hline Low & 0.074 & 0.258 & 0.188 & 0.196 \\
\hline Medium & 0.117 & 0.296 & 0.216 & 0.232 \\
\hline High & 0.136 & 0.362 & 0.253 & 0.179 \\
\hline \multicolumn{5}{|l|}{ Contrasts } \\
\hline Early vs. late & 0.102 & - & - & $<0.001$ \\
\hline Triticale vs. dry pea & 0.097 & 0.338 & 0.282 & 0.412 \\
\hline Foxtail vs. proso & 0.203 & - & - & 0.299 \\
\hline Low vs. high & 0.015 & 0.002 & 0.050 & 0.507 \\
\hline
\end{tabular}

$\dagger$ Triticale and dry pea were planted in early April while foxtail and proso millets were planted in early June.

harvest index for wheat following early planted summer crops averaged 0.162 compared with 0.243 following late planted summer crops. Angus and van Herwaarden (2001) refer to this negative yield response, when vigorous vegetative growth is followed by a terminal drought, as haying off. At Akron, the smaller difference in starting soil water for wheat between the early and late planted crop treatments, combined with nearnormal seasonal precipitation, both in terms of quantity and timing, resulted in no crop treatment differences.

\section{Annualized Net Return}

Annualized net return for the 2-yr system of summer fallow replacement crop and winter wheat was greatest in the high water treatment in three of the four site-years (Table 8). Only at Sidney in 2005-2006 were there no differences in annualized net return between water treatments. This may partially be explained by above average fall and early spring precipitation in 2004-2005, which restricted the range of beginning soil water levels

Table 8. Influence of previous summer crop and starting soil water level on the annualized net return (USD, U.S. dollars) of the summer crop and the subsequent winter wheat crop at Akron, CO, and Sidney, NE.

\begin{tabular}{|c|c|c|c|c|}
\hline \multirow[b]{2}{*}{ Treatment } & \multicolumn{2}{|c|}{ Akron, CO } & \multicolumn{2}{|c|}{ Sidney, NE } \\
\hline & 2004-2005 & $2005-2006$ & 2004-2005 & 2005-2006 \\
\hline & & -USI & $1 a^{-1}$ & \\
\hline \multicolumn{5}{|l|}{ Crop } \\
\hline Triticale & $22 \mathrm{~A} \dagger$ & $157 \mathrm{~A}$ & $24 \mathrm{~A}$ & $176 \mathrm{C}$ \\
\hline Dry pea & $-133 B$ & $-169 B$ & $-149 B$ & $-159 D$ \\
\hline Foxtail millet & $18 A$ & - & - & 239B \\
\hline Proso millet & $-6 A$ & - & - & 333A \\
\hline \multicolumn{5}{|l|}{ Soil water level } \\
\hline Low & $-87 \mathrm{c}$ & $-\mathbf{3 3 b}$ & $-118 \mathrm{c}$ & $140 a$ \\
\hline Medium & $-19 b$ & $-15 b$ & $-70 b$ & $151 a$ \\
\hline High & 31a & $29 \mathbf{a}$ & $\mathbf{0 a}$ & 151a \\
\hline
\end{tabular}

$\dagger$ Means within a column and treatment category followed by the same letter and in the same case are not significantly different from one another at the 5\% probability level. 
created by supplemental irrigation prior to planting the 2005 summer crops at Sidney.

There were no mean annualized net returns that were negative for the high water treatments. This demonstrates the importance of planting a summer fallow replacement crop only when water in the top $120 \mathrm{~cm}$ of soil is at least $70 \%$ of field capacity at the time of summer crop planting.

At Akron, annualized net return to the summer crop and winter wheat was no different between any of the crop treatments except for dry pea, which had a much lower annualized net return in both years. The same was true at Sidney in 2004-2005. The high cost of pea seed $\left(\$ 3.30 \mathrm{~kg}^{-1}\right.$, USD) had a strong negative influence on profitability. Above-average April through August precipitation at Sidney in 2005 resulted in excellent summer crop yields, particularly for foxtail and proso millet, which along with good wheat yields contributed to the profitability of these 2-yr summer fallow replacement cropping systems.

\section{CONCLUSIONS}

Felter et al. (2006) reported that soil water at planting could be a useful indicator of potential yield for some crops, particularly annual forage crops, used as partial summer fallow replacements prior to winter wheat seeding in late summer. The results of this study suggest that soil water at the time of planting the summer fallow replacement crop also impacts the subsequent winter wheat crop, although the impact is not to the extent that it affects the summer crop. This makes the decision to either plant a summer crop or to summer fallow prior to winter wheat that much more critical.

The selection of a short-season summer fallow replacement crop may not be as critical as the decision to plant a crop or not, but it still can influence the performance of the subsequent winter wheat crop and the financial return to the farmer. The high cost of dry pea seed, combined with the lack of consistent response of dry pea to soil water at planting (Felter et al., 2006), makes dry pea a poor choice for a flexible summer fallow cropping system despite the agronomic benefits that a legume may provide. Although it was only observed at Sidney in 2005-2006, it is intuitive that soil water at winter wheat seeding is likely to be greater following early rather than late planted summer crops as a result of the increased time between harvest and winter wheat seeding for the former compared with the latter. It is also likely that soil water at wheat seeding would be greater after a forage crop compared with a grain crop as a result of reduced water use during the shorter growing season and subsequent increased time from harvest to wheat seeding. Since increased soil water at winter wheat seeding is usually positively related to winter wheat yield (Musick et al., 1994; Nielsen et al., 2002; Stone and Schlegel, 2006), it would be reasonable, although not always true, that winter wheat yield would be greater after an early planted forage crop like triticale compared with a late planted grain crop like proso millet.
Results from Felter et al. (2006) and this study suggest that a flexible summer fallow cropping system may be feasible for the Central Great Plains. Determining a threshold soil water level at which to plant a summer fallow replacement crop will be critical to the success of the system since it will not only influence the performance of the summer crop but also that of the subsequent winter wheat crop. The flexible summer fallow cropping system appears to be most applicable when using short-duration summer annual forage crops, such as triticale and foxtail millet. Forage yield is more readily estimated by soil water at planting than is grain yield and the shorter duration of forage compared with grain crops tends to leave more soil water for the subsequent winter wheat crop. However, grain crops such as proso millet, with low seed cost and a relatively good grain price, may also be feasible if a grower is willing to accept a greater variability in economic return, that is, greater risk.

\section{ACKNOWLEDGMENTS}

This work was partially funded by the Nebraska Wheat Board. Their support is appreciated. We thank Robert Higgins and Albert Figueroa for their excellent management of the research plots at Sidney, NE, and Akron, CO.

\section{REFERENCES}

Angus, J.F., and A.F. van Herwaarden. 2001. Increasing water use and water use efficiency in dryland wheat. Agron. J. 93:290-298.

Dao, T.H. 1993. Tillage and winter wheat residue management effects on water infiltration and storage. Soil Sci. Soc. Am. J. 63:186-191.

Daugovish, O., D.J. Lyon, and D.D. Baltensperger. 1999. Cropping systems to control winter annual grasses in winter wheat (Triticum aestivum). Weed Technol. 13:120-126.

Dhuyvetter, K.C., C.R. Thompson, C.A. Norwood, and A.D. Halvorson. 1996. Economics of dryland cropping systems in the Great Plains: A review. J. Prod. Agric. 9:216-222.

Farahani, H.J., G.A. Peterson, and D.G. Westfall. 1998. Dryland cropping intensification: A fundamental solution to efficient use of precipitation. Adv. Agron. 64:197-223.

Felter, D.G., D.J. Lyon, and D.C. Nielsen. 2006. Evaluating crops for a flexible summer fallow cropping system. Agron. J. 98:1510-1517.

Greb, B.W. 1979. Reducing drought effects on cropland in the westcentral Great Plains. USDA Bull. 420. U.S. Gov. Print. Office, Washington, DC.

Greb, B.W. 1983. Water conservation: Central Great Plains. p. 57-72. In H.E. Dregne and W.O. Willis (ed.) Dryland agriculture. Agron. Monogr. 23. ASA, CSSA, and SSSA, Madison, WI.

Jones, O.R., and T.W. Popham. 1997. Cropping and tillage systems for dryland grain production in the southern High Plains. Agron. J. 89:222-232.

Klocke, N.L., and G.W. Hergert. 1990. How soil holds water. NebGuide G90-964. Univ. of Nebraska, Lincoln.

Krupinsky, J.M., K.L. Bailey, M.P. McMullen, B.D. Gossen, and T.K Turkington. 2002. Managing plant disease risk in diversified cropping systems. Agron. J. 94:198-209.

Lyon, D.J., D.D. Baltensperger, J.M. Blumenthal, P.A. Burgener, and R.M. Harveson. 2004. Eliminating summer fallow reduces winter wheat yields, but not necessarily system profitability. Crop Sci. 44:855-860.

Lyon, D.J., F. Boa, and T.J. Arkebauer. 1995. Water-yield relations of several spring-planted dryland crops following winter wheat. J. Prod. Agric. 8:281-286.

McGee, E.A., G.A. Peterson, and D.G. Westfall. 1997. Water storage efficiency in no-till dryland cropping systems. J. Soil Water Cons. 52:131-136.

Musick, J.T., O.R. Jones, B.A. Stewart, and D.A. Dusek. 1994. Water- 
yield relationships for irrigated and dryland wheat in the U.S. southern plains. Agron. J. 86:980-986.

Nielsen, D.C., R.L. Anderson, R.A. Bowman, R.M. Aiken, M.F. Vigil, and J.G. Benjamin. 1999. Winter wheat and proso millet yield reduction due to sunflower in rotation. J. Prod. Agric. 12:193-197.

Nielsen, D.C., P.W. Unger, and P.R. Miller. 2005. Efficient water use in dryland cropping systems in the Great Plains. Agron. J. 97:364-372.

Nielsen, D.C., and M.F. Vigil. 2005. Legume green fallow effect on soil water content at wheat planting and wheat yield. Agron. J. 97: 684-689.

Nielsen, D.C., M.F. Vigil, R.L. Anderson, R.A. Bowman, J.G. Benjamin, and A.D. Halvorson. 2002. Cropping system influence on planting water content and yield of winter wheat. Agron. J. 94:962-967.

Norwood, C.A. 1994. Profile water distribution and grain yield as affected by cropping system and tillage. Agron. J. 86:558-563.

Peterson, G.A., A.D. Halvorson, J.L. Havlin, O.R. Jones, D.J. Lyon, and D.L. Tanaka. 1998. Reduced tillage and increasing cropping intensity in the Great Plains conserves soil carbon. Soil Tillage Res. 47:207-218.

Peterson, G.A., A.J. Schlagel, D.L. Tanaka, and O.R. Jones. 1996. Precipitation use efficiency as affected by cropping and tillage systems. J. Prod. Agric. 9:180-186.

Peterson, G.A., and D.G. Westfall. 2004. Managing precipitation use in sustainable dryland agroecosystems. Ann. Appl. Biol. 144:127-138.

Peterson, G.A., D.G. Westfall, and C.V. Cole. 1993. Agroecosystem approach to soil and crop management research. Soil Sci. Soc. Am. J. 57:1354-1360.

SAS Institute. 2001. SAS v. 8.0. SAS Inst., Cary, NC.

Stone, L.R., and A.J. Schlegel. 2006. Yield-water supply relationships of grain sorghum and winter wheat. Agron. J. 98:1359-1366.

Tanaka, D.L., and J.K. Aase. 1987. Fallow method influences on soil water and precipitation storage efficiency. Soil Till. Res. 9:307-316.

Unger, P.W. 1984. Tillage and residue effects on wheat, sorghum, and sunflower grown in rotation. Soil Sci. Soc. Am. J. 48:885-891. 